\title{
Confronting the International Order: Changes in US Foreign Policy from the Perspective of American Power Elites
}

\author{
Andrzej Mania \\ Jagiellonian University \\ Institute of Political Science and International Relations \\ e-mail: andrzej.mania@uj.edu.pl
}

\section{Tomasz Pugacewicz}

Jagiellonian University

Institute of Political Science and International Relations

e-mail: tomasz.pugacewicz@uj.edu.pl

\section{Abstract}

The aim of this article is to present the most important voices on the role of the US in the international order during Donald Trump's presidency in the debate held in the Foreign Affairs. The authors assume that Foreign Affairs expresses the opinions of the most crucial organisation bringing together the elites of American foreign affairs - the Council on Foreign Relations. The paper proposes a hypothesis according to which there is a difference of opinion due to the adopted theoretical perspective regarding Trump's role in the destruction of the liberal international order among the American power elites, even though they agree that the ideological conflict between democratic and authoritarian countries around the world is escalating.

Keywords: United States, international order, Donald Trump, Foreign Affairs, Council on Foreign Relations, US power elite, international relations theories, ideological rivalry, Russia, China. 


\section{Introduction}

The aim of the paper is to present the most important voices on the role of the US in the international order during Donald Trump's presidency in the debate held in the Foreign Affairs bimonthly journal. The authors assume that Foreign Affairs expresses the opinions of the most important organisation bringing together the elites of American foreign affairs - the Council on Foreign Relations (CFR). In consequence, the discussion held in the journal reflected the debate among the US power elites. The present paper poses a hypothesis that there is a difference of opinion due to the adopted theoretical perspective regarding Trump's role in the destruction of the liberal international order among the American power elites, even though they agree that the ideological conflict between democratic and authoritarian countries is escalating. The research strategy rests with the case study approach, within which qualitative text analysis serves as a data collection method.

\section{The Foreign Affairs journal and the Council on Foreign Relations}

The Council on Foreign Relations was formally established in 1921 as a fusion of two communities: an informal club, operating in New York that brought together over 100 wealthy American entrepreneurs and lawyers since 1918, and The Inquiry think tank established in 1917 by President Th. Woodrow Wilson as a foreign affairs advisory body. The members of The Inquiry took active part in the Paris Peace Conference in 1919 (Grose, 1-9; Mania, 159-176) ${ }^{1}$.

To this day, CFR maintains its hybrid nature. On one hand, it is an elite membership organisation encompassing over 5000 of "the most prominent leaders in the foreign policy arena, including top government officials, renowned scholars, business executives, acclaimed journalists, prominent lawyers, and distinguished non-profit professionals" (Individual Membership). The members must have US citizenship, meet multiple criteria, and pay annual fees between approximately USD 300 and 4000 (Annual Membership Dues). However, the membership fees constitute only $10 \%$ of its income, which was USD 69 million in 2017. Its main sources are interest on capital, donations, Foreign Affairs activity, external grants, and corporate memberships (Funding). The president of CFR for the last sixteen years has

1 CFR published its history twice: The Council on Foreign Relations; Grose. See also: Schulzinger. CFR's influence on the US foreign policy was thoroughly analysed twice: Parmar; Wala 1994 (it is a translation of Wala 1990). See also papers on CFR relations with business written from the leftist point of view: Shoup and Minter; Shoup 2015. 
been Richard N. Haass, former Policy Planning Staff head in the Department of State during George W. Bush's presidency (Richard N. Haass).

On the other hand, CFR continues its analytical activity by conducting the David Rockefeller Studies Program. Currently, CFR employs temporarily or permanently 70 experts (Think Tank). The results of their work are available at https://www. cfr.org/think-tank, a website independent from the journal's website. The financing of the aforementioned programme relies mainly on interest on capital, grants from foundations, and corporate payments. In 2017, its budget was almost USD 14 million (Funding). Since 2009, the head of this section of CFR has been James M. Lindsay - a recognised scholar with experience in managing think tanks and former employee of the National Security Council (NSC) (James M. Lindsay).

According to the complex ranking carried out by James G. McGann (University of Pennsylvania), in 2017, the Council on Foreign Relations was the eighth most influential think tank in the US (McGann 2018, 62, 75, 96, 110, and 173). It is usually classified as a centrist think tank (McGann 2005, 12; Trimbath, 41; Think Tanks), but some consider it liberal (Trimbath, 41).

Two years after its establishment, the Council on Foreign Relations started publishing the Foreign Affairs journal, first as a quarterly, and currently as a bimonthly (History). Longer texts appear in the printed version, whereas the shorter ones are available at www.foreignaffairs.com (Submissions). Since 2010, the editor in chief has been Gideon Rose, working in the journal since 2000, previously a lecturer and NSC employee (Staff).

In mid-2017, it had over 210 thousand paid subscriptions, while its circulation was over 350 thousand copies. The number of newsletter subscribers was similar - 340 thousand, and its website had almost one million of unique users a month (Circulation). Despite the fact that the papers published in Foreign Affairs are not reviewed in the typical manner and lack some characteristics of academic papers, such as footnotes, the journal has the Impact Factor of 2.536 (as of 2016) and is the seventh most often quoted among the 86 International Relations journals in the world. In the prestigious survey Teaching, Research \& International Policy (TRIP) from 2014, approx. 800 scholars considered Foreign Affairs the second most important journal of the discipline (List the four journals...). In the post-Cold War period, the journal was sometimes (e.g., in 2006) even considered the most influential in the US (Foreign Affairs Again...).

This paper assumes that the texts published in Foreign Affairs reflect the perspective of CFR, which is representative for (centrist or centrist-liberal) foreign affairs elites of the US. This approach builds on the idea of epistemic communities, encompassing governmental and non-governmental institutions, that are specialised in a particular sector of public policy (Abelson, 27-28) ${ }^{2}$. It is worth noting that

2 More on foreign policy from the domestic perspective (including think tanks) - see: Pugacewicz. 
this is only one of many ways of seeing the role of think tanks in a state, because, according to the leading expert in the field, D. Abelson (20-29), they can be also considered as (1) a type of interest group fighting for impact with other groups (e.g. chambers of commerce); (2) an instrument for pursuing the interests of power elites on whose funds think tanks depend; (3) a group of people only those of whom who were employed, at the request of those in power, have any meaning in the political system ${ }^{3}$.

\section{Trump and the (liberal) international order in Foreign Affairs}

The subject of the analysis are articles from twelve issues of Foreign Affairs published between the official nomination of D. Trump on the Republican Party convention (September/October 2016) and the submission of this paper (July/August 2018) 4 .

In the first two issues, there were no texts directly referring to the role of the US under the leadership of Donald Trump in the international order. However, four papers presented the stances of people responsible for shaping the US foreign policy (Joseph Biden, John Kerry, Ashton Carter, and Martin Dempsey). The authors decided to analyse Biden's statements, as they were the most closely related to the subject of the paper.

Joseph R. Biden (46-58) presented not only the perception of the role of the US in the international order as of the end of the second term of Barack Obama, but also some suggestions for the new president. He emphasised that together with President Obama, they had assumed that the American leadership in the world was based on dynamic economy, military potential, and universal values. However, not only the domestic potential, but also the network of alliances with other countries and the international order based on particular rules and institutions turned out to be decisive. Vice-president Biden underlined that the USA had built the world order after the Second World War and were likely to keep leading it in the twenty first century. Nevertheless, he also cautioned: "If the next administration chooses to turn inward, it could very well squander the hard-earned program we've made not just over the past seven and half years but also over the past seven decades".

He advised the new president that the US should engage on both sides of the Pacific Ocean, as many issues required it. He pointed out domestic and trans-national problems in South America and key allies on the other side of the Pacific Ocean:

3 See also the author's opinion on lack of theoretical studies on the role of think tanks in the decision-making process (Abelson, 13-14).

4 The papers on international order that were published only at the websites www.foreignaffairs. com or https://www.cfr.org/think-tank are excluded from the analysis. See e.g. Mazarr 2018. 
Australia, Philippines, Japan, and South Korea. At the same time, relations with China and members of Association of Southeast Asian Nations (ASEAN) should be developed. The defence of the Trans-Pacific Partnership (TPP) should be a priority, because it encompasses twelve economies constituting $30 \%$ of global trade, $40 \%$ of global GDP, and 50\% of projected global growth. Biden recommended maintaining proper relations with China while taking a firm position on human rights, intellectual property protection, and freedom of navigation. In case of Russia, he opted for deterrent policy with possibility of tactical cooperation. He insisted on maintaining the sanctions introduced after the annexation of Crimea. He also recommended taking interest in the security of Poland and Baltic states. At the same time, he emphasised the need of international cooperation concerning environment protection threats, malware, and extremist ideologies. To sum up, Biden strongly recommended an active international policy.

The first issue of Foreign Affairs in 2017 was titled Out of Order? The Future of the International System and consisted of six papers on international order (Rose, C9; Haass 2017a, 2-9; Nye, 10-16; Niblett, 17-24; Mazarr 2017, 25-32; Feigenbaum, 33-40; Schake, 41-46). Among them, Joseph S. Nye's paper is the most related to the analysed problems.

Professor Nye (author of Is the American Century Over?) recognised the threats emerging from the fact that the US - despite their military, economic, and soft power potential - may abandon these resources and stop maintaining the existing international order. Such populist statements were heard during the presidential campaign, based on the conviction of white Trump voters that in thirty years, they would not be the majority in the U.S. anymore. In this and similar populist statements, the end of the globalist era and the beginning of the upcoming chaos are observed. It is hard to conclude much from election's rhetoric, but criticism towards TTP and Transatlantic Trade and Investment Partnership (TTIP) emerged.

However according to Nye, it did not mean the return of the protectionism of the 1930s. Opinion polls conducted by the Chicago Council on Global Affairs in 2016 showed that $65 \%$ of Americans considered globalisation favourable for the USA despite the fear of job losses. Moreover, Pew Survey indicated that $51 \%$ of Americans thought that immigrants strengthened the US. As a result, it could be concluded that the existing order was not doomed.

Nye wondered what the US, spending approx. 4\% of their GDP on defence and foreign affairs, representing half the amount spent during the Cold War, could do about it. It is still an enormous potential allowing also for the activity outside the country. However, the society is not in favour of interventions and significant involvement in international matters. This is the era of terrorism and migration crisis, which worries US citizens much more. Nevertheless, there are regions such as the Middle East, where US involvement is unavoidable. Due to its potential, the United States must cooperate with other states and international organisations. 
It has to be clearly stated that "Leadership is not the same as domination" and that cooperation with others with the objective of maintaining the order is now more important than it used to be ${ }^{5}$.

In 2017, in the March/April issue of "International Affairs", two papers on the international order in general (by Walter Russell Mead and Stewart M. Patrick) and several on important elements of this order (among other things, on the relations between USA and Russia, China, North Korea, or world economy) were published (Mead, 2-7; Patrick, 52-57; Rumer et al., 12-19; Shirk, 20-27; Lind, 74-82; Delury, 46-51). The authors decided to further analyse two general texts and the articles on Russia and China.

The appointment of President Trump made multiple analysts face his point of view and, in consequence, the US policy regarding the most important issues. The topic of the clash of American populism and liberal world order was present already during the elections, as Professor Mead noted. He referred to his own concept of four historical traditions present over the years in the US foreign policy. He points out that there has been no such a fundamental debate on foreign policy referring to historical divisions since Franklin D. Roosevelt.

His first two concepts assumed the functioning of the US in the centre of the world order. The so-called Hamiltonians believed that the duty of the US was to replace the United Kingdom as world's leader defining the directions of the world order. As a result, the US were obliged to deter the USSR and when it fell, promote the liberal order, mostly in economy. The Wilsonians also believed in world order, as it was in line with US interests, but focused on values, not on economy. Given the weakness of many countries, they started promoting human rights, democratic order, and the rule of law. Some of them, the so-called liberal institutionalists, focused on international organisations and were in favour of increased integration. What is important, both fractions opted for world order.

However, nationalistic voices advocating lack of involvement in nation building and - in a sense - turning away from the world grew louder and louder. In consequence, two other approaches - Jeffersonian and Jacksonian - returned to favour. The Jeffersonians, including contemporary realists, assumed that reducing American involvement would reduce costs and risk in foreign policy. They limited the US interests to the narrow economic aspect. The libertarians, taking an extreme position, looked for supporters on the left, which opposed interventions and wanted to reduce arms expenditure, calling the authorities to focus on internal affairs. During the presidential campaign, Senator Rand Paul from Kentucky and Senator Ted Cruz from Texas adopted this position.

However, Trump sniffed the wind better. He assumed that the USA citizens did not expect Jeffersonian minimalism, but rather Jacksonian populist nationalism.

5 See also the following monographs: Lieber; Cohen 2016; Haass, 2017b. 
The Jacksonian populism barely focuses on foreign policy, seeing many threats inside the community, for example in the rule of weak and non-patriotic elites taking the side of "African Americans, Hispanics, women, the LGBTQ community, Native Americans, Muslim Americans". For such voters, the right to bear arms and hostility towards integration and political correctness are the key values. The Jacksonians are not satisfied with the US foreign policy and do not accept trade agreements, which they consider unfavourable. This attitude reflects judgments rooted in intuition and populist prejudices rather than knowledge of politics. In case of foreign policy, the main factor is nationalism. Such voters assumed that Trump was on their side.

Another article from Foreign Affairs is stricte about Trump's approach to the world order (Patrick, 52-57). Since F. D. Roosevelt, the US has declared in diverse ways their involvement in the world order and have been a global leader. According to Patrick, Trump announces that foreign policy will be nationalist and focused on the defence of US interests. However, Trump has not presented any vision of the new order. He will not take into account the consequences for the world order in his actions concerning foreign and economic policy. He announces reconsideration of existing alliances, trade agreements, introducing barriers in the trade with China, withdrawal from the Paris climate pact, and rejection of the settlement of Iranian nuclear programme. As a result, some countries - forming diverse coalitions - will oppose such policy, which may be unfavourable for the US. Other countries will adapt, seeing no other choice than maintaining relations with the US. Each of these attitudes will affect the forming international order, or rather disorder.

Patrick argues, that observing the world and the worsening situation provides clear data on an obvious change in the international order in terms of geopolitics, economy, and climate change.

In terms of geopolitics, the US have been in the position to manage the system through military dominance strengthened by locating the armed forces in many regions of the world, providing the nuclear umbrella, and treaty commitments to defend the allies from aggression. Trump may infringe it, as he undermines the credibility of such solutions. Many states will start securing themselves through other configurations letting the US know and demanding more autonomy. For Europe, this attitude will weaken the transatlantic links, lead to the need to increase own arms, and to constant balance between the US and Russia, whereas Baltic states may face the threat or need of Finlandisation.

In terms of economy, Trump wants to overthrow or significantly reshape NAFTA, as well as undertake actions against TTP. WTO practice will become protectionist. Asian partners will start joining alternative structures, such as the Regional Comprehensive Economic Partnership (RCEP) and contesting American leadership in the International Monetary Fund (IMF) and World Bank. G-20 will become more important than G-7. 
The difference of opinions can be observed also in environment protection. Trump does not consider the planned climate-related restrictions relevant despite the fact that the majority of countries are ready to support them.

According to Patrick, it is a paradox that Trump announced that the objective would be to reduce the dependence and risk for the US from the world in terms of politics and economy, but the side effect of such actions may be limiting the potential and weakening the position of the US.

In the same issue of the journal, an article by three analysts on one particular question of the contemporary international order - the relations between the US and the Russian Federation - was published (Rumer et al., 12-19). The authors reminded about the poor state of these relations due to the annexation of Crimea, war in Eastern Ukraine, and Russian policy in Syria. At the same time, Russia states it takes all these steps to defend itself from US and NATO aggression. These analysts recommended to Trump's administration the adoption of five guidelines concerning Russia: (1) clearly commit to help NATO allies through, among other things, expanding own potential and pressure on increased armament of NATO members; (2) remind Russia about the Helsinki Accords of 1975 and the Paris Charter of 1990 on the recognition of borders; even though the return of Crimea to Ukraine is unlikely, it has to be demanded and the sanctions kept; (3) engage in regions bordering Russia to support them; (4) support Ukraine and its reforms together with NATO; and (5) support democracy in Russia and former Soviet states.

US policy towards China became the net focus of interests of Foreign Affairs (Shirk, 20-27, see also: Lind, 74-82), which cited the opinions that in thirty years, Chinese economy would be bigger than the American one, and it already had an advantage in international trade. China is indeed able to deal with huge social and economic problems, as proven during the crisis in 2008. China acts confidently, has protectionist policy, demands modern technologies from the Western world, while maintaining restrictions for foreign business within its borders and taking control of the areas on the South China Sea against the maritime law, refusing arbitration. Taking the above into consideration, the U.S. should: (1) maintain the network of alliances in Asia, particularly with Japan and South Korea; (2) stop China's actions constituting a direct threat to the USA (e.g. concerning discrimination of importers); (3) reach out to social groups such as businesspersons, as they can lobby opening up the economy in China; (4) maintain relationships with representatives of important Chinese institutions and build their trust; (5) prevent anti-Chinese attitudes in the US; and (6) clearly express the expectation of support from China.

The May/June 2017 issue of Foreign Affairs included two papers on international order (by G. John Ikenberry (2-9), and Jeff D. Colgan and Robert J. Keohane (26-44) and one piece by Matthew Kroenig (30-34) on selection of personnel in Trump's administration. 
In his paper, Professor Ikenberry states that the fall of the liberal order should be due to the actions of hostile powers and democratic states should unite to protect it (Ikenberry, 2-9, see also: Colgan and Keohane, 36-44). However, the state that created this order now devastates it. Trump is against the post-war system, trade, multilateralism, environment protection, and human rights in many aspects. The dominant slogan is America First. Trump believes that his predecessors made "horrible deals" and the US are surrounded by Islamic terrorism, immigrants, and crime, which have to be resisted. The challenge thrown by Trump at the liberal order is particularly dangerous, as it is built on lack of respect for the standards of liberal democracy (e.g. courts).

For the liberal order to survive, the world has to unite, and the Prime Minister of Japan together with the German Chancellor should play a major role in it. It is not easy, as this order is already compromised and weakened. Trump's disregard for US achievements in creating the order based on multiple alliances and the UN after the Second World War makes it even more difficult. Trump sees international affairs as transactions. Someone gains and someone loses in a particular deal. He does not see the logic of interdependence. Small victories in particular deals do not create a safe order. If the US abandon the current order, diverse configurations supporting or destroying it will emerge, and China will fill the gap.

Professor Ikenberry states that not everyone in Trump's administration attacks the international system. For example, in the economic aspect, a part of Trump's administrations is aware of the threats due to Trump's lack of faith in free trade, cultivated in the US since the Reciprocal Trade Agreement Act of 1934 and later within WTO. Trump is in favour of mercantilist approach and "win or lose" system, so he withdraws from TPP and wants to renegotiate NAFTA. He considers the EU a German tool "to beat the United States on trade".

Many politicians are concerned about his attitude towards multilateral rules and institutions, which were created and supported mainly by the US (i.e., UN, IMF, international arms control regime, and human rights conventions). Trump does not show any respect for these rules. He rejects the assumption, present in the US foreign policy since Wilson, that the community of liberal democracies may exist and cooperate guaranteeing order.

Ikenberry concludes that defending the order is the rational thing to do. Therefore, attempts to convince Trump that his America First policy is misguided are necessary and Prime Minister Abe together with Chancellor Merkel must maintain the existing order until the end of Trump's government.

Trump's supporters also write about forming administration and policy in Foreign Affairs. One of them is Kroenig (30-34). He quotes Henry Kissinger, who considers Trump's administration "an extraordinary opportunity" for American foreign policy. According to Kroenig, the world after Obama's presidency is more dangerous than it was in 2009. China increases its armaments, North Korea 
has 21 nuclear warheads, and the Middle East is disintegrating due to ISIS actions. Trump's somewhat unsuccessful start may later help US regain its position in the world, as he employed the "best and brightest", such as James Mattis and H.R. McMaster mentioned above. Moreover, former CEO of ExxonMobil, Rex Tillerson, was appointed Secretary of State, Mike Pence vice-president, Nikki Haley ambassador with the UN, Dan Coates director of national intelligence, and Mike Pompeo director of the CIA. They form a very valuable team. Steve Bannon, whose qualifications are dubious, was fired.

Moreover, Kroenig rejects the accusations that the slogan America First practically brings an end to American leadership. He states that it is not true, as Trump's administration is very active in domestic policy, which guarantees international success. The exchange turnover value and the budget of the Department of Defence are increasing. Relations with Japan are good and relations with NATO, which is no longer considered obsolete, are improving. Trump conducts harsh policy towards Russia, appointing Fiona Hill from Brookings Institution Senior Director for European and Russian Affairs of the NSC. He struggles to improve the conditions of American trade, believing that "free trade has to be fair trade".

In the next issue of Foreign Affairs (July/August 2017), two papers on Trump's foreign policy - by Richard N. Haass and Elliott Abrams - were published (Haass 2017c, 2-9; Abrams, 10-16).

In the discussion about the directions of foreign policy, the statement of the aforementioned CFR president is particularly important (Haass 2017c, 2-9). Contrary to Kroenig, Haass believes that Trump forms his team exceptionally slowly and formally delays the declaration of the directions of foreign policy. As a result, many decisions are made in passing.

Haass states that Trump was right that the development of North Korean nuclear potential was the greatest threat and that the current sanction system did not work. Therefore, the president has three options: acceptance, military intervention, and creative diplomacy. Acceptance will not assure safety for the US. Even if North Korea does not attack, it may pass the weapons to other and cause South Korea and Japan to build their nuclear potentials. Military intervention may be either preventive (moving deliberately to destroy a gathering threat) or preemptive (moving quickly to head off and immediate one). It means that North Korea would directly attack a part of the territory of South Korea, which surely prefers to avoid it. The least attractive option is left - negotiations. How to do it? In two stages. First, there should be a temporary agreement on suspending nuclear and missile programmes. The second stage should consist of an agreement to reduce and fully eliminate the programmes.

Haass recommends approaching the question of Taiwan, South China Sea, etc. with caution in relations with China in order not to expose American interests. Under the new circumstances, the US should be ready to raise the issues of monetary 
manipulation, governmental subsidies, and intellectual property theft. Simultaneously, they should act in support of extending TPP rather than against it.

According to the head of CFR, the US should assume that even though EU is not perfect, it is the source of stability and welfare, so they should support integration.

In Haass's opinion, using the so-called super bomb to attack Syria in response to the biological weapon attack was a correct reaction. Turkey is an ally, but not a real partner because of its authoritarian order and treatment of Kurds despite their support in the war against ISIS. The agreement with Iran is not perfect, but it is fortunate that the president did not reject it, as it would mean losing control over Iran. Now, the US have to demand full compliance with it. He also suggested that the US should not engage too much in conflicts involving Saudi Arabia. It seems that neither Palestine nor Israel are likely to seek an agreement. The US should act with caution in order not to worsen the situation and should not move the embassy to Jerusalem.

Years ago, George W. Bush asked whether China was ready to act as a "responsible stakeholder" in the international system. The head of the CFR thinks we may now ask the same question about America.

Trump declared that the US would not engage in the affairs of other countries. It is understandable, but burdensome, as seen in the instances of "careless tyrants", such as leaders of Egypt, Philippines, or Turkey. Finally, the president should understand that whatever he says about American institutions, judiciary, Congress, or media, is heard in the world and can affect the respect towards the US and may encourage some to challenge the rule of checks and balances.

Haass believes that Trump should reduce and change the rhetoric regarding trade. Technological innovations are much more responsible for job losses in the US than trade or off-shoring, so protectionism will only encourage others to introduce it too and will make the situation on the US labour market worse. Business security training programmes, plans for workers losing their jobs, and domestic investments need improvements and development.

Haass argues that in terms of climate protection, the lack of acceptance of the fact that climate change is due to human activity is incomprehensible. The multilateral agreement not affecting the sovereignty of the US that has been established in Paris has to be accepted.

The head of the CFR points out that Trump's erroneous concept of administration forming is due to his lack of understanding of its complexity. As a result, many positions are vacant or temporarily delegated to officers. The president prefers an informal decision-making process rather than relying on formal structure of the NSC in foreign and security affairs. Trump boasts about his predilection for shocking people with the unexpected and a general unpredictability; this may work on tactical level, but does not contribute to achieving strategic goals. Maintaining 
uncertainty makes sense in case of enemies, but not friends and allies. The Twitter diplomacy intensifies this impression.

According to Haass, breaching the existing order the US benefit from is unreasonable. The existing international order is in crisis and many of its elements require modernising and replenishment in terms of globalisation effects. The strategic goal of the American policy should be protection and adaptation, not destruction.

In Haass's eyes, the slogan America First ${ }^{6}$ is unfortunate, as it suggests downsizing the activities of American foreign policy and lack of wider perspective. The President seems to agree with many Americans for whom the expenditures on foreign affairs are too high and at the expense of their own country. For the allies, it means that they are not in the centre of American strategy. Actions aiming at targeting American patriotism at maintaining the global leadership are necessary.

The paper on the directions of administration policy by Abrams, who is an analyst and politician associated with the current administration, seems interesting (Abrams, 10-16) 7 . Abrams admitted that Trump's first statements and actions seemed unpredictable and inconsistent. There were no new mid-level appointments, but it does not make Trump's administration revolutionary. During a certain period, many were concerned that it would be a "Bannonite administration" or "Breitbart presidency". It was due to the appointment of Steve Bannon as a NSC Principal Committee member. He inspired to an extent the indiscretions such as the harsh words about NATO and slow rearmament of Europe, the gesture towards Taiwan that infuriated China, the defence of Putin followed by the question to the Americans "What, you think our country's so innocent?". However, the president gradually abandoned such actions: he expressed a different opinion on NATO, criticised Russia, and Mike Flynn was ousted from his post of National Security Advisor. Finally, Trump appointed respected generals, Mattis, Kelly, McMaster, and Tillerson to high-level positions. Pompeo, a Harvard graduate, became the director of the CIA. In the context of the critique of Trump, using the so-called super-bomb in Syria to defend justice and international standards and not the American world was surprising. It was meant to defend human rights, not democracy, as this administration is against nations building. On the other hand, human rights were not mentioned in front of President Xi Jinping, which is not unusual for the US in relations with states they want to cooperate with (e.g. Reagan acted the same way in front of President Ferdinand Marcos in 1982).

The next three issues of Foreign Affairs (October/November 2017-January/February 2018) did not feature any paper on Trump's foreign policy in the context of international order, apart from Andrew J. Bacevich's text on the concepts of

6 See a critical analysis of the use of this term in American tradition: Bacevich, 57-67.

7 The author of this paper was appointed deputy secretary of state by R. Tillerson. 
American exceptionalness (Bacevich, 57-67). Only in the subsequent issue (March/ April 2018) titled Letting Go, Trump's actions in foreign policy up to date and their influence on the international order were summarised (Rose 2018, C9). Three papers by Eliot A. Cohen (2018, 2-9), Jake Sullivan (10-19), and Barry R. Posen (20-27) were particularly important.

The first of the aforementioned scholars, a recognised military historian and author of the book The Big Stick: the Limits of Soft Power and the Necessity of Military Force, stated that Trump's rhetoric after the swearing in was not far from his nationalist populism of his campaign. However, his actions are an unpredictable version of the traditional policy of the Republican Party, as proven by increased expenses on armaments, readiness to use the armed force, or support for the allies.

Cohen emphasizes that the lack of significant negative consequences of Trump's policy for the US is not a result of wise decisions, but sheer luck, as there has been no domestic crisis or attack on an ally. It is due to the deliberation of the members of Congress, judges, and federal officers, who act in accordance with the consensus elaborated in the US after the Second World War. It is possible, because Trump installed his people on only $40 \%$ of high-level positions during the first year of his presidency.

According to Cohen, this situation cannot last indefinitely, as the establishment may no longer be able to hinder Trump or one of the crises may intensify. A fortiori that "the Trump administration has not solved any of the problems it inherited". Each of these creases may aggravate in 2018, whereby the position of the US on the international level is worse in terms of dealing with them than a year earlier. The danger is also that the aggravation of one crisis will make the enemies of the US try to push their interests through in the remaining regions.

On the other hand, Sullivan (10-19), former head of the Policy Planning Staff of the Department of State, stated that the growing number of states undermining the liberal international order had been emphasised and that the position of the US as its guarantor decreased in relation to the remaining participants. The emergence of a new order or an era of chaos were expected. However, it turned out that "rumors of the international order's demise have been greatly exaggerated", as it can resist even the adverse actions of its very architect and leader. It is due to the fact that other states benefit from the existing order and want to maintain its fundaments. At the same time, the US took steps to make the rules of the international order more flexible encouraging the creation of regional rules based on voluntary approach. This, however, does not alter the fact that the existing order cannot be maintained without some corrections due to the increasing challenges and expectations of the emerging powers. The fate of the aforementioned order depend on whether Trump will be elected for the second term.

Posen $(20-17)$ indicated that, despite the promises made during his presidential campaign, Trump did not put the US on the track of isolationism and rejection of 
the existing international order. In fact, he actively involves the US, in particular its armed forces, in international matters. As a result, the new president, just like his predecessors, wants to maintain military and economic dominance in the world. However, he rejected its liberal model - he does not support multilateral institutions fostering common values or promote democracy among other states. Thus, Posen concludes that Trump turned out to be in favour of the US hegemony, but not its liberal kind.

The May/June 2018 issue of Foreign Affairs brought one paper about the international order. Its authors, Yascha Mounk and Roberto Stefan Foa (29-36), pointed out that the dominance of democratic states was coming to an end after a century. So far, democracy has been attractive not only because of political ideas, but also because of material success of free market economy accompanying it. However, the importance of military and economic power of democratic states is currently decreasing for the benefit of non-democratic states developing state capitalism. In 2018, for the first time in 100 years, the share of world GDP of democratic states is below $50 \%$ and will decrease to approximately one third during the next decade. Non-democratic states, although in the early 1990s, they produced only $12 \%$ of world GDP, are now responsible for $33 \%$ of it (a similar situation could be observed in the 1930s). If the current trends persist, within the next five years, the share of world GDP of non-democratic states will become larger than the share of democracies. As a result, democracy becomes less attractive economically, while authoritarian soft power and the ability of non-democratic states to interfere with internal affairs of the democracies are increasing. If economic development does not lead to democratisation of non-democratic states, the era of dominance of democracy will end with the times of ideological rivalry.

Finally, three papers on international order appeared in the July/August 2018 issue.

In his paper written from the realist point of view, Stephen Kotkin (10-15) stated that the so-called liberal international order was a form of organising and expanding the US zone of influence to assure their domination in the world. Although the sphere of influence was not motivated by altruism, but in the US' own interest, "voluntary alliances, multilateral institutions, and free trade" replaced the alternative of direct subordination. Military and economic domination of the US made building such an order easier.

However, the current position of the US in the world is limited due to two crises. Firstly, the power of the US is decreasing, which reduces their ability to maintain the international order it forced through. The increase of power of China and Russia leads to the increase of soft power of their economic model and their dedication to building their own zones of influence based on their own international order rules. Secondly, the US have a dysfunctional domestic political system within which the elites aspire to promote globalisation in the world, which provides profits 
to domestic economic hubs and leads to the development of world economy (including, paradoxically, political rivals) in general, but at the same time contributes to the crisis of domestic economic peripheries, which makes them more likely to support economic nationalism ${ }^{8}$.

Daniel Deudney and already mentioned Ikenberry (16-24) wrote their paper from the perspective of the liberal theory. They emphasise that even though antiliberal tendencies on the domestic (shift away from democracy because of growing disproportions of income) and international (increase of power of non-democratic China and Russia, abdication of the UK and US) levels are increasing, they are optimistic about the future. Firstly, they believe that only democracy is able to solve the modern problems and the rising ideological rivalry will enforce the reforms aimed at increasing solidarity in democratic states. Secondly, only international institutions formed within the liberal international order are able to ensure security and stable development of states in the world of growing interdependence. They derive their value from the fact that those institutions are "Westphalian, in that they are designed merely to solve problems of sovereign states, whether they be democratic or authoritarian".

At the same time, the authors point out to the limited extent of Trump's destructive actions aimed at international institutions of the liberal international order. Firstly, in some areas, "despite Trump's relentless demeaning of the international order, he has sometimes acted in ways that fulfil, rather than challenge, the traditional American role in it" (e.g. sanctioning Syria for chemical weapons). Secondly, challenging US membership in organisations such as NATO and WTO faces resistance of domestic interest groups whose long-term interests are related with these institutions. As a result, Trump's actions “... have generated a great deal of anxiety and uncertainty, but their actual effect is less threatening - more a revisiting of bargains than a pulling down of the order itself". Thirdly, in cases where Trump's actions breach the liberal order, other states are committed to sustaining it (e.g. after the US withdrawal from the TTP, it was signed nevertheless).

The last paper from this issue was written by Graham Allison (124-133) who states that the concept of liberal international rules-based order is based on three elements: (1) "that the liberal order has been the principal cause of the so-called long peace among great powers for the past seven decades"; (2) "that constructing this order has been the main driver of US engagement in the world over that period"; and (3) "that US President Donald Trump is the primary threat to the liberal order - and thus to world peace". According to Allison, each of these statements is false, because: (1) for the last 70 years, peace has been the result of the Cold War balance of powers between the US and USSR and, later, the post-Cold War military

8 See our previous observation on uneven distribution of profits from globalisation in American society: Mania and Pugacewicz, 247-259. 
dominance of the US; (2) the current international order is a result of the US pursuit of their own objectives, because they did not hesitate to break the rules of the order to defend these objectives; (3) "although Trump is undermining key elements of the current order, he is far from the biggest threat to global stability", because the decrease of the power of the US in the world and the increase of the power of China and Russia are a much bigger threat.

From this point of view, Allison does not consider Trump to be the cause of the breach of international order, but a symptom of the crisis of American political elite, which is unable to provide the conditions for the development of democracy in the US. In consequence, American authorities should focus on creating appropriate conditions for the development of domestic democratic institutions and limit the involvement on the international level, because "it will be enough to sustain a world order 'safe for diversity' - liberal and illiberal alike”.

\section{Conclusions}

To conclude, at the beginning of the first year of Trump's presidency, positive opinions of the previous administration and recommendations to maintain the liberal international order prevailed in Foreign Affairs. Simultaneously, analysed authors expressed concerns that the declarations of the new president suggested challenging the current position of the US in the world order.

In the context of Trump's actions, the assessment of the existing international order in the discussed papers varied depending on the position regarding the theory of international relations.

The liberals pointed out that democracy was the only system able to solve the contemporary problems and the liberal international order defined as cooperation within international organisations was the only warranty that there would not be a global catastrophe due to increasing interdependence. They emphasised that Trump challenged the assumptions of the liberal international order only partially, as the opponents of his policy were present on the level of both international system and domestic political system. At the same time, they indicated that the new president aimed at building an international order assuring the US freedom of decision and more accepting towards non-democratic entities.

On the other hand, the realists have less faith in the durability of the liberal international order. They believe that also non-democratic states are able to solve contemporary problems and take care of economic development. They consider the liberal international order merely a form of the American sphere of influence, the extent of which is set by military and economic power of the United States. The increase of power of non-democratic states will lead to formation of their own zones of influence based on the rules of international order they push through. 
Regardless of their theoretical stance, the authors of the analysed articles mostly agree that the upcoming years will see a heightened rivalry between democratic and non-democratic ideologies. It is a result of the increase of power of non-democratic states, including their soft power, and the decline of the importance of democratic countries. Therefore, the US have to get used to living in a world of diverse systems. The future of democratic states does not rely on the promotion of democracy outside their borders, but on the ability of the elites of already democratic states to rebuild the bases assuring the stability of their own systems (e.g. economic solidarity).

\section{Works Cited}

Abelson, D. Theoretical Models and Approaches to Understanding the Role of Lobbies and Think Tanks in US Foreign Policy. Policy Expertise in Contemporary Democracies. Ed. Stephen Brooks, Dorota Stasiak, and Tomasz Zyro. Burlington: Ashgate, 2012.

Abrams, E. Trump the Traditionalists. A Surprisingly Standard Foreign Policy, "Foreign Affairs", no. 96.4 (2017), pp. 10-16.

Allison, G. The Myth of the Liberal Order From Historical Accident to Conventional Wisdom, "Foreign Affairs", no. 97.4 (2018), pp. 124-133.

Annual Membership Dues. Council on Foreign Relations. Web. 14 Sep 2018, https:// www.cfr.org/sites/default/files/report_pdf/CFRMemberDues-July2017.pdf.

Bacevich, A.J. Saving "America First". What Responsible Nationalism Looks Like, "Foreign Affairs", no. 96.5 (2017), pp. 57-67.

Biden, J.R. Building on Success, Opportunities for the Next Administration. "Foreign Affairs", no. 95.5 (2016), pp. 46-58.

Circulation. "Foreign Affairs". Web. 14 Sep 2018, https://www.foreignaffairs.com/ circulation.

Cohen, E.A. The Big Stick: The Limits of Soft Power and the Necessity of Military Force. New York: Basic Books, 2016.

Cohen, E.A. Trump's Lucky Year. Why the Chaos Can't Last. "Foreign Affairs”, no. 97.2 (2018), pp. 2-9.

Colgan, J.D. and Robert O. Keohane. The Liberal Order Is Rigged. Fix it Now or Watch It Wither. "Foreign Affairs", no. 96.3 (2017), pp. 36-44.

Delury, J. Trump and North Korea. Reviving the Art of the Deal. "Foreign Affairs", no. 96.2 (2017), pp. 46-51.

Deudney, D. and G.J.I. Liberal World. The Resilient Order. "Foreign Affairs", no. 97.4 (2018), pp. 16-24.

Feigenbaum, Evan A. China and the World. "Foreign Affairs", no. 96.1 (2017), pp. 33-40. 
Foreign Affairs Again Ranked Most Influential of All Media by US Opinion-Leader Study. Council on Foreign Relations. Web. 14 Sep 2018, https://www.cfr.org/news-releases/ foreign-affairs-again-ranked-most-influential-all-media-us-opinion-leader-study Funding. Council on Foreign Relations. Web. 14 Sep 2018, https://www.cfr.org/ who-we-are/funding.

Grose, P. Continuing the Inquiry: The Council on Foreign Relations from 1921 to 1996. New York: Council on Foreign Relations Press, 1996.

Haass, R.N. A World in Disarray: America Foreign Policy and the Crisis of the Old Order. New York: Penguin Press, 2017b.

Haass, R.N. Where to Go From Here. Rebooting American Foreign Policy. "Foreign Affairs", no. 96.4 (2017c), pp. 2-9;

Haass, R.N. World Order 2.0. "Foreign Affairs", no. 96.1 (2017a), pp. 2-9.

History. "Foreign Affairs". Web. 14 Sep 2018, https://www.foreignaffairs.com/history. Ikenberry, G.J. The Plot Against American Foreign Policy. Can the Liberal Order Survive. "Foreign Affairs", no. 96.3 (2017), pp. 2-9.

Individual Membership. Council on Foreign Relations. Web. 14 Sep 2018, https://www. cfr.org/membership/individual-membership.

James M. Lindsay. Council on Foreign Relations. Web. 14 Sep 2018, https://www.cfr. org/experts/james-m-lindsay.

Kotkin, S. Realist World. The Players Change, but the Game Remains. "Foreign Affairs", no. 97.4 (2018), pp. 10-15.

Kroenig, M. The Case for Trump's Foreign Policy. The Right People, the Right Positions. "Foreign Affairs", no. 96.3 (2017), pp. 30-34.

Lieber, R.J. Retreat and Its Consequences: American Foreign Policy and the Problem of World Order. New York: Cambridge University Press, 2016.

Lind, J. Asia's Other Revisionist Power. Why US Grand Strategy Unnerves China. "Foreign Affairs", no. 96.2 (2017), pp. 74-82.

List the four journals that publish articles with the greatest influence on the way IR scholars think about international relations. TRIP Faculty Survey All Countries Combined (Sep. 9, 2014). Web. 14 Sep 2018, https://trip.wm.edu/charts/\#/ bargraph/38/5068.

Mania, A. Europa Środkowa w celach polityki USA w latach I wojny światowej. 14 punktów Wilsona. Państwa europejskie na drodze do niepodległości: (w drugiej połowie XIX i XX wieku): studia ofiarowane Profesorowi Marianowi Zgórniakowi. Ed. Irena Stawowy-Kawka and Wojciech Rojek. Kraków: Historia Iagellonica, 2003.

Mania, A., and Pugacewicz, T. Wybrane elementy kondycji Stanów Zjednoczonych u progu prezydentury Donalda Trumpa [Selected aspects of the United States' condition on the threshold of Donald Trump's presidency]. "Rocznik Strategiczny", no. 22 (2017), pp. 247-259. 
Mazarr, Michael J. The Once and Future Order. "Foreign Affairs", no. 96.1 (2017), pp. 25-32.

Mazarr, Michael J. The Real History of the Liberal Order: Neither Myth Nor Accident. "Foreign Affairs" (Aug. 7, 2018). Web. 14 Sep 2018, https://www.foreignaffairs. com/articles/2018-08-07/real-history-liberal-order.

McGann, J.G. 2017 Global Go To Think Tank Index Report. Philadelphia: University of Pennsylvania, 2018.

McGann, J.G. Think Tanks and Policy Advice in the US. Philadelphia: Foreign Policy Research Institute, 2005.

Mead, W.R. The Jacksonian Revolt. American Populism and the Liberal Order. "Foreign Affairs", no. 96.2 (2017), pp. 2-7.

Mounk, Y. and Foa, R.S. The End of the Democratic Century. Autocracy's Global Ascendance. "Foreign Affairs", no. 97.3 (2018), pp. 29-36.

Niblett, R. Liberalism in Retreat. "Foreign Affairs", no. 96.1 (2017), pp. 17-24.

Nye, J.S. Will the Liberal Order Survive? "Foreign Affairs", no. 96.1 (2017), pp. 10-16.

Parmar, I. Think tanks and power in foreign policy: a comparative study of the role and influence of the Council on Foreign Relations and the Royal Institute of International Affairs, 1939-1945. New York: Palgrave Macmillan, 2004.

Patrick, S.M. Trump and World Order. The Return of Self-Help. "Foreign Affairs", no. 96.2 (2017), pp. 52-57.

Posen, B.R. The Rise of Illiberal Hegemony. Trump's Surprising Grand Strategy. "Foreign Affairs", no. 97.2 (2018), pp. 20-27.

Pugacewicz, T. Teorie polityki zagranicznej. Perspektywa amerykańskiej analizy polityki zagranicznej [Theories of foreign policy: American foreign policy analysis Perspective]. Kraków: Wydawnictwo Uniwersytetu Jagiellońskiego, 2017.

Richard N. Haass. Council on Foreign Relations. Web. 14 Sep 2018, https://www.cfr. org/experts/richard-n-haass.

Rose, G. Letting Go. "Foreign Affairs", no. 97.2 (2018), p. C9.

Rose, G. Out of Order. "Foreign Affairs", no. 96.1 (2017), p. C9.

Rumer, E.B. Richard Sokolsky, and Andrew S. Weiss. Trump and Russia. The Right Way to Manage Relations. "Foreign Affairs", no. 96.2 (2017), pp. 12-19.

Schake, K. Will Washington Abandon the Order? "Foreign Affairs", no. 96.1 (2017), pp. 41-46.

Schulzinger, R.D. The Wise Men of Foreign Affairs: The History of the Council on Foreign Relations. New York: Columbia University Press, 1984.

Shirk, S. Trump and China. Getting to Yes With Beijing. "Foreign Affairs", no. 96.2 (2017), pp. 20-27.

Shoup, L.H. Wall Street's think tank: the Council on Foreign Relations and the empire of neoliberal geopolitics, 1976-2014. New York: Monthly Review Press, 2015.

Shoup, L.H. and William Minter. Imperial brain trust: the Council on Foreign Relations and United States foreign policy. New York: Monthly Review Press, 1977. 
Staff. "Foreign Affairs". Web. 14 Sep 2018, https://www.foreignaffairs.com/staff\#PUB. Submissions. "Foreign Affairs". Web. 14 Sep 2018, https://www.foreignaffairs.com/ submissions- 0 .

Sullivan, J. The World After Trump. How the System Can Endure. "Foreign Affairs", no. 97.2 (2018), pp. 10-19.

The Council on Foreign Relations: A Record of Twenty-five Years, 1921-1946. New York: Council on Foreign Relations, 1947.

Think Tank. Council on Foreign Relations. Web. 14 Sep 2018, https://www.cfr.org/ think-tank.

Think Tanks. New York Times (Aug. 10, 2008). Web. 14 Sep 2018, https://ideas.blogs. nytimes.com/2008/08/10/think-tanks/.

Trimbath, S. Think Tanks: Who's Hot. "The International Economy: the Magazine of International Economic Policy" (2005), pp. 10-15, 39-47.

Wala, M. Council on Foreign Relations and American foreign policy in the early Cold War. Providence: Berghahn Books, 1994.

Wala, M. Winning the peace: amerikanische Außenpolitik und der Council on Foreign Relations, 1945-1950. Stuttgart: F. Steiner, 1990.

Andrzej Mania - Professor title awarded by the President of Poland in 1993. Since 1997, Professor at the Institute of Political Science and International Relations and head of the Chair of Diplomatic History and International Politics. Simultaneously, since 1994, head of the Chair of American Studies. Between 2008 and 2016, Vice-Rector for Educational Affairs of the Jagiellonian University. Member of the Steering Committee of the International Research University Network (2008-2012). Chairman of the Steering Committee of the Sasakawa Young Leaders Fellowship Fund of the Tokyo Foundation at the Jagiellonian University. Fellow or visiting professor in more than ten foreign institutions, including Norwegian Nobel Institute in Oslo, Kennan Institute of Advanced Russian Studies in Washington and the University of Rochester. Authored or co-authored ten books, including The Department of State 1789-1939 (Jagiellonian University Press, Krakow 2011). Editor of another six books. Member of the Lions Club International (Krakow Stare Miasto).

Tomasz Pugacewicz - PhD, Assistant Professor at the Jagiellonian University in Kraków. The theoretical aspects of his $\mathrm{PhD}$ dissertation were published in the monograph Teorie polityki zagranicznej. Perspektywa amerykańskiej analizy polityki zagranicznej [Theories of Foreign Policy. American FPA Perspective] (Jagiellonian University Press, Kraków 2017). During his internships abroad, he was a visiting researcher at the Johns Hopkins University, the State University of New 
York, and the Heidelberg University. In 2018, he received a grant from the Polish National Science Centre for the project titled "Between Center and Periphery: A Comparison of Ludwik Ehrlich's Theoretical Concepts with American-British International Relations in the First Half of the Twenty Century". Holder of several scholarships, e.g. the scholarship of the Copernicus Society in America. In 2015, he participated in the Ideas Lab - the Young Professionals Programme at the Chancellery of the President of the Republic of Poland. 